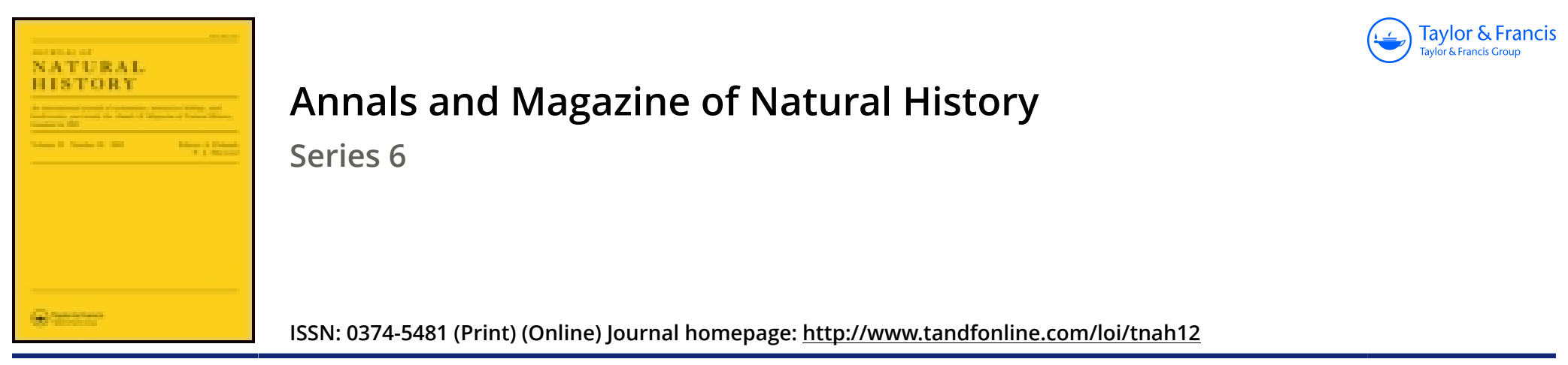

\title{
LIII.-Description of a new species of Mus from South Australia
}

\section{Oldfield Thomas}

To cite this article: Oldfield Thomas (1889) LIII.-Description of a new species of Mus from South Australia, Annals and Magazine of Natural History, 3:17, 433-435, DOI: 10.1080/00222938909460363

To link to this article: http://dx.doi.org/10.1080/00222938909460363

曲 Published online: 09 Oct 2009.

Submit your article to this journal $\sqsubset \pi$

Џ Article views: 1

Q View related articles $₫$

4 Citing articles: 1 View citing articles 진 
Dr. Jullien's critical remarks on the classification of the Pedicellinida I hope to notice on some future occasion.

\section{EXPLANATION OF PLATE XXI.}

Fig. 1. Scrupocellaria scubra, Van Beneden. Form destitute of vibracula. Fig. 2. Smittia producta, Packard.

Fig. 3. Macronella spinulifera, $\mathrm{n}$. sp.

Fig. 4. Porella concinna, Busk, var.

Fig. 5. Porella acutirostris, Smitt. a. Orifice of zooecium. $b$. That of $P$. concinna.

Fig. 6. Rhamphostomella costata, Lorenz, var. cristata.

Fig. 7. The same. Group of marginal cells.

Fig. 8. The same. Young cells, showing the superficial costre.

Fig. 9. Pedicellina mutons, Dalyell.

Fig. 10. Barentsia gracilis, Sar's. (Fur comparison with $B$. mijor, Hincks, 'Annals' for March 1888, pl. xv. fig. 2.)

\section{LIII.-Description of a new Species of Mus from South Australia. By Oldfield Thomas.}

\section{MLus argurus, sp. $\mathrm{n}$.}

Size about equal to that of a small Mus nanus or large $M$. albo-cinereus. Fur crisp or even slightly spinous. General colour above pale sandy rufous, the hairs slate-coloured at their bases. Ears very thinly covered with fine white hairs, rounded, laid forward they reach just beyond the middle of the eye. Muzzle and underside of body white, the line of demarcation on sides not sharply marked; hairs of chest and belly pale rufous basally. Hands and feet pure white. Soles smooth, naked, with six well-developed rounded pads, the posterior one elongated. Tail rather longer than the head and body, quite uniform in colour above and below, more thickly covered with hairs than usual, the hairs pure white, the scales (which average about thirteen or fourteen to the centimetre) pale flesh-coloured; tip of tail slightly pencilled. Palate-ridges nine, three anterior undivided and six divided, interdental, of which the anterior is directly transverse, while the others are slanted backwards mesially.

Skull smooth and unridged. Nasal and interorbital regions flat, evenly convex when viewed in profile; supraorbital edges sharply square, but not beaded or ridged. Interparietal broad antero-posteriorly, its diameter in this direction more than half its transverse breadth. Anterior edge of 
outer wall of infraorbital foramen evenly convex, not overhanging above, or hollowed out below. Palatine foramina reaching to just between the anterior corners of the first molars. Posterior nares broad, the spine in the centre of the posterior edge of the palate unusually well developed. Bullæ small, transparent.

Teeth.-Incisors pale orange above, yellow below. Upper molars (see fig.) very narrow and elongated, their inner cusps

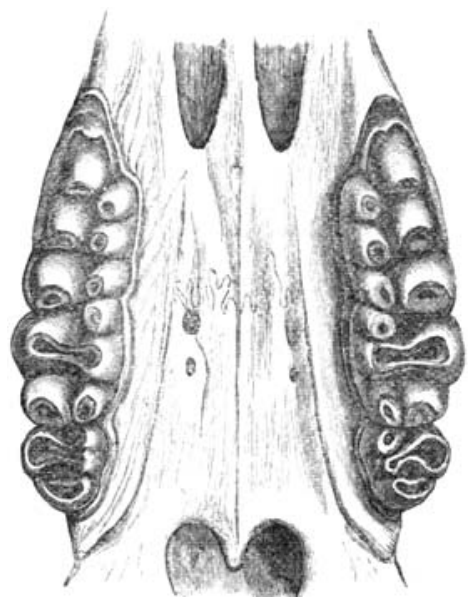

Mus argurus. Upper molar teeth, magnified about $\tau$ diameters.

all along unusually well developed, while their outer ones are almost obsolete. $\stackrel{M .1}{-}$ with a small secondary cusp on its anterior side, exactly as in the Indian Leggada*; laminæ three in number as usual, but the external cusps on these laminæ extraordinarily reduced, obsolete on the first and third laminæ, and nearly so on the second; on the other hand, the inner cusps are very large, the third lamina even, which generally has no internal cusp, having one quite as large as the others. M1.2 with two laminæ as usual, each of which has its small internal cusp, in addition to the antero-internal cusp always present in Mus, there being therefore three internal cusps to

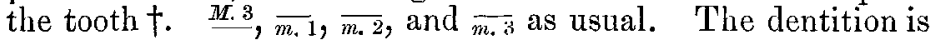

* See Proc. Zool. Soc. 1881, p. 552, pl. li. fig. 10.

† This fact is most important, as it seems to me to negative Dr. Winge's suggestion ("Jordfundne og Nulevende Gnavera fra Lagoa Santa," E Mus. Lund. iii. p. 125, 188\%) that the ordinary antero-internal cusp of this tooth in Mus is that originally belonging to the first lamina, while that opposite this lamina really belongs to the next one, the two having been pushed out of their normal positions by the increase in size of the 
therefore very similar to that found in certain members of the genus Hapalotis, and particularly in H. hirsutus, Gould, of which the molars are almost identical in structure with those of the present species.

Dimensions of the type, an adult male in spirit :-

Head and body 83 millim.; tail 101; hind foot 22 ; ear 14 ; forearm and hand 25 ; head to front of last foot-pad 10.3 ; length of last foot-pad $2 \cdot 4$. Skull: basal length 24.6 ; greatest breadth $14 \cdot 0$; nasals, length 11.2 ; interorbital breadth $4 \cdot 8$; interparietal, length $5 \cdot 0$, breadth $8 \cdot 3$; length of outer wall of infraorbital foramen $3 \cdot 1$; palate, length $16^{\circ} 0$, breadth outside $\stackrel{m_{.1}}{\longrightarrow} 5.9$, inside $\stackrel{m .1}{ } 3.0$; diastema $7 \cdot 9$; length of anterior palatine foramina $5 \cdot 5$, of upper molar series $5 \cdot 5$.

Hab. South Australia.

Mus argurus has therefore the external characters and the skull of Mus, with the molars of Hapalotis ; and I am somewhat in doubt as to which of the two it should be put into. It seems indeed probable that the characters of these two genera will be found so to blend together in the different species as to necessitate their ultimate union, notwithstanding the very striking characters presented by the more typical species of Hapalotis.

Pending a general revision of the Australian Muridæ, however, I refier the present new form to Mus, the differences in the teeth appearing not to be of very great systematic importance, while its external form, and especially the proportions of its hind feet, are wholly those of Mus, and in no way recall those of the Jerboa-like Hapalotis.

Of species already described none can be confounded with this, as, apart from its peculiar teeth, it is readily distinguished from all by its wholly white tail.

\section{BIBLIOGRAPHICAL NOTICE.}

Bulletin Scientifique de la France et de la Belgique. Publié par

A. Giard. Tome xix. 8vo. Paris: Octave Doin, 1888.

Iv the year 1869 M. Alfred Giard, then Professor in the "Faculté des Sciences" at Lille, started a new periodical under the title of "Bulletin Scientifique du Département du Nord et des Pays voisins."

other cusps. That the internal cusp attached to the anterior lamina really belongs to it, and not to the second lamina, has always appeared to me far more natural, and the state of things in Mus argurus and in Hapalotis strongly supports this view. 